Izvorni znanstveni rad

DOI: 10.17234/Croatica.41.14

UDK: 821.163.42-22.09Držić, M.

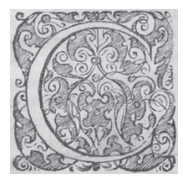

\title{
SMIJEŠNO I/ILI KOMIČNO U BRAČNOM ŽIVOTU DRŽIĆEVIH LIKOVA
}

\author{
Boris Senker \\ Filozofski fakultet Sveučilišta u Zagrebu \\ boris.senker@ffzg.hr
}

Polazeći od dviju rasprava Dunje Fališevac, o starom Freudu u posjetu Marinu Držiću te o rezigniranom renesansnom "junaku" Tripčetu, potom od teze da se renesansne komedije razvijaju "u dvije istodobno dobro uređene sekvence: naraciju i retoričku raspravu" (Levenson 1990) i podjele prikaza muško-ženskih odnosa u tri etape koje se prema S. Greenblattu nazivaju "prosidba, vjenčanje i pokora", u ovom se priopćenju tematiziraju obrasci udvaranja i prosidbe u Grižuli i Skupu, donekle i u Dundu Maroju, potom jedino uprizoreno vjenčanje, u Arkulinu, i napokon "nevoljni brakovi” kao "pokora" u komediji Tripče de Utolče. Ističu se, dakako, njihova smiješna i komična obilježja.

Ključne riječi: Marin Držić, renesansna komedija, obrasci udvaranja, smiješno i komično

Brak i komedija u dugoj su i neraskidivoj vezi još od nove atičke i rimske komedije. U jedinoj posve sačuvanoj Menandrovoj komediji, Mrzovoljniku, riječ je o čak tri braka. Evo njezina sažetka kako ga je sročio "gramatičar Aristofan":

Mrzovoljnik se oženi ženom koja je već otprije imala sina. Ona ga ubrzo ostavi zbog njegove nepodnošljive naravi: otada sam s kćerkom živi na imanju. U djevojku se smrtno zaljubi Sostrat i dođe je prositi. Mrzovoljnik se usprotivi. Mladić privolje njezina brata, no ovaj nije mogao ništa učiniti. Knemom [mrzovoljnik], 
međutim padne u bunar: Sostrat mu smjesta pritekne u pomoć. Stari se pomiri sa ženom, a djevojku dragovoljno dade Sostratu za zakonitu ženu. Sostratovu sestru, odobrovoljen, uze za ženu Georgiji, svome pastorku (Menandar 1981: 51).

Budući da se "sa stajališta utjecaja", kako je ustvrdio Erich Segal, "Menandra s dobrim razlozima može smatrati najutjecajnijom osobom u povijesti zapadne komedije" (Weitz 2009: 50), ne iznenađuje što u dobrom dijelu komedija nastalih na tragu nove atičke pa rimske komedije, uključujući i renesansne koje nas ovdje zanimaju, dinamiku radnje određuju u jednom nizu primjera prepreke koje mladi par mora svladati ne bi li na kraju stupio u brak za koji se dakako pretpostavlja da će biti dobar, sretan, što će reći da će postati temeljem nove obitelji kao osnovne društvene jedinice. Te su prepreke ponajčešce neskloni roditelji, suparnici u ljubavi ili neprikladno podrijetlo jednoga od zaljubljenika. U drugom se nizu primjera javljaju prepreke koje muž i/ili žena moraju svladati ne bi li uredili odnose u lošem braku ili iz njega izašli, barem privremeno ako ne i trajno. Menandar je u Mrzovoljniku, vidljivo je već iz "gramatičarova" sažetka, isprepleo i svladavanje prepreka na putu prema dobrom braku i uređivanje odnosa u lošem braku, a narav je naslovnoga lika uzrok svih nedaća.

Prema povjesničarki drame Jill Levenson, renesansna komedija koja se oslanja o antičku i humanističku tradiciju

prikaz je koji se u vremenu razvija u dvije istodobne dobro uređene sekvence: naraciju i retoričku raspravu. Naracija napreduje kroz tri faze kojih se proporcije mogu razlikovati: ekspoziciju i početak radnje, zapletanje zbivanja te anastrofu ili razrješenje. Karakteristično je za tu sekvencu da počinje greškom koja izaziva pomutnju što će se na kraju razriješiti u sretnom završetku. Usporedo se u nizu debata raspravlja o središnjem pitanju jednako kao i o sporednim temama (Levenson 1990: 264).

U komedijama, recimo tako, "na bračne teme", a u takve se komedije može ubrojiti i nekoliko tekstova Marina Držića, s jedne strane "naracija" prati rješavanje problema vezanih uz sklapanje, održavanje ili, napokon, razvrgavanje braka, a s druge strane "retorička rasprava"s različitih stajališta propituje brak kao jednu od temeljnih društvenih ustanova. Rasprava se dakako može proširiti i na druge teme, prije svega na rodne uloge i rodne odnose u danom društvu te na odnose bračnoga para ili njegova jednog člana s ostalim članovima obitelji.

Priopćenje o smiješnom i komičnom u bračnom životu Držićevih likova potaknuto je dvjema studijama Dunje Fališevac, naime onom o starom 
Freudu u posjetu Marinu Držiću (Fališevac 2007) i o rezigniranom renesansnom "junaku” Tripčetu (Fališevac 2013).

Iz prve studije preuzimam razlikovanje smiješnoga i komičnoga, kako je ono zasnovano prije svega u austrijsko-njemačkoj teoriji: "[D]ok se smiješno javlja u opreci prema socijalno uvjetovanim normama te često služi satiri, komično je u svojem događajnom karakteru otkrivanje misaone, smislene proturječnosti između dva različita nivoa, dvije razine čovjekova bića." Te: "[K]omično ne izaziva nužno smijeh, ali [...] uvijek razveseljuje" (Fališevac 2007: 107-108).

Druga je rasprava poticajna zbog dokazivanja središnjeg položaja braka u komediji Tripče de Utolče, odnosno Mande:

Komedija je komponirana prepletanjem triju fabularnih linija, odnosno ima tri zapleta, pri čemu sve priče problematiziraju muško-ženske odnose, konkretno probleme nevoljnog braka, bračnog trokuta, a kroz to na izvjestan način i tjelesnog, seksualnog života. Radnja je smještena u Kotor - da li stoga što Držić nije želio temu braka i bračne nevjere smjestiti u Dubrovnik i predstaviti dubrovačke žene kao lukavice i preljubnice ili zbog toga što je mogao na tuđem prostoru [...] kritički i satirički predstaviti instituciju braka, a time i obiteljske odnose - teško je reći. Jesu li tema i smisao komedije kritika i napad na brak kao instituciju, možda na brak iz računa, može li se komedija shvatiti kao subverzivna predodžba braka, društvenih odnosa u privatnom životu, kao kritika običajnog, licemjernog morala, ili u njoj treba tražiti odgovore na pitanje o vitalnosti spolova, o moći ženskog, nagonskog, prirodnog, zdravog, mladenačkog nad muškim, staračkim, bolesnim načelom [...] - i to je teško reći (Fališevac 2013: 124-125).

Sljedeći poticaj dolazi pak iz šekspirologije, točnije iz monografije Will u vremenu, kako je izvorni naslov Will in the Woorld preveo Dinko Telećan (Greenblatt 2010). Poglavlju u kojem govori o istovrsnoj temi, naime o muško-ženskim odnosima i o braku u Shakespearea, autor Stephen Greenblatt dao je naslov Prosidba, vjenčanje i pokora (Wooing, Wedding, and Repenting). Pogledajmo može li se o analognim etapama, te o smiješnom i komičnom u njima, govoriti i u Držića. Počet ćemo, dakako, s prvom etapom, s prosidbom, kojoj može, ali ne mora, prethoditi udvaranje. Uostalom, i Greenblatt u tom poglavlju govori i o jednom i o drugom.

Premda se renesansni tipizirani likovi mladih zaljubljenika javljaju i u Držićevim komedijama - primjerni su u tom pogledu Kamilo i Andrijana u Skupu - izravna ljubavna očitovanja za njih ne bi bila dolična pa funkciju posrednika, sukladno pravilima eruditne komedije, preuzimaju njihovi "djetići” i "godišnice". Tako je u Držića izravna razmjena verbalnih i never- 
balnih, prije svega gestovnih iskaza ljubavi i bračnih nakana, prožetih jačom ili slabijom seksualnošću, uglavnom ograničena na te posrednike koji, prenoseći jedni drugima poruke svojih gospodara gospodaricama i obratno, nerijetko postaju njihovi komični ili smiješni pandani. ${ }^{1}$ Reklo bi se da je najprivlačnija mlada žena u Držićevu komičkom teatru Petrunjela, "djevojka Laurina" (Dundo Maroje). Izlazeći iz Laurine kuće i ulazeći u nju, ona na rimski trg donosi i nešto od ozračja što vlada u toj kući, kući ljubavi. Privučeni njezinim seks appealom, kako bi se reklo danas, izravno joj se, kadikad i napasno udvaraju i Pomet, i Popiva, i Tripčeta iz Kotora, pa i trio mladih Dubrovčana, zapravo dvojica iz tog trija, Niko i Pijero, jer se "mjedeničar" (Dundo Maroje, II, 2, str. 329) Vlaho drži postrani. Pitanje komu će ona na kraju komedije, ako uopće hoće, dati pristanak te s kim će i hoće li uopće u naviještenom "tercijarnom vremenu"2 stupiti u brak, ostaje otvoreno zbog toga što je Držićeva "anastrofa" izgubljena. Pomet je izbor koji je bliži renesansnom shvaćanju braka kao skladnoga i produktivnog (u biološkom i gospodarskom smislu) partnerstva mladih žena i muškaraca, Popiva pak izbor bliži poznomu građanskom shvaćanju braka kao gubitka slobode za muškarca. ${ }^{3}$ Budući da su Držićevom rukom pisana konačna priopćenja odluka o tomu tko će komu pripasti i u Skupu i u Dundu Maroju izgubljena, kao primjer izravnoga udvaranja i prosidbe u Držića navodim neznatno skraćen Sedmi prizor Prvoga čina Grižule. U njemu Rade i Mionica vode razgovor u kojemu se erotika provlači kroz slike iz seoske i pastirske svakodnevice:

1 Prenošenje poruka nije jednolično. Kadikad zaljubljenikov "djetić” prenosi gospodarovu poruku "godišnici" ljubljene, a ona će ju prenijeti gospodarici. Istim će se putom kretati i odgovor. Kadikad, premda rijetko, posrednik se obraća izravno ljubljenoj, primjerice Pomet Lauri, ali ona je rimska kurtizana, a ne dubrovačka "djevojčica". Nešto je češća komunikacija između zaljubljenika i "godišnice" njegove ljubljene, primjerice Uga i Petrunjele. (Svi navodi dalje u tekstu preuzeti su iz izdanja: Marin Držić, Djela, priredio, uvod i komentare napisao Frano Čale, Centar za kulturnu djelatnost, Zagreb, 1987.)

2 Prema Manfredu Pfisteru, "tercijarno dramsko vrijeme [je] fiktivno trajanje priče od početka verbalno posredovane pripovijesti pa do časa kojim se tekst završava, odnosno do onoga najkasnijeg termina koji se na kraju teksta još verbalno tematizira kao perspektiva u budućnosti” (Pfister 1998: 397).

3 Tako u Mihovila Kombola, koji je svoju nadopunu Dunda Maroja shvaćao dokraja epigonski, kao što točniju i posve neosobnu rekonstrukciju izgubljenoga kraja komedije, Pomet odlučuje u Laure isprositi Petrunjelu za sebe, a ona to pjesmicom prihvaća, a Marko Fotez u adaptaciji i nadopuni Dunda, rađenoj za ukus i nazore međuratne zagrebačke publike, Petrunjelu, također Pometovom odlukom, dodjeljuje Popivi, gotovo kao podvalu, a za sebe zadržava slobodu. 
$R A D E$ : Mione, tako sjetna ne hodila, uzmi ti mene: ja neću bježat, vazda ti ću i od ručka i od večere štogodi dohranjevat. A meni vazda baba ušne i kad se siri i kad se mijesi.

MIONICA: Bijedan Radoje, upitomi paganioce koje s gnijezdom onomad nađe, i oblakomi se na nje!

$R A D E$ : Za tebe ih hranim, Mione, a maja veli vazda: 'S Mionom čuva' živo'. A kad ti ću, Mione, ukazat gnijezdo staglina koji lijepo poju?

MIONICA: Ne smijem od majke!

$R A D E$ : Ali ja ću maji rijet da te isprosi.

MIONICA: Brižan, tako mi nećeš ni od ručka donijet?

$R A D E$ : Bogme ti ću i pločicu zaimat, ter ćeš pticam zapinat.

MIONICA: Bijedna nestala! Stado mi se rasprša, a Dragića vile uzeše, a Gruba i ne znam kud pođe.

$R A D E$ : Tužan se ja zagovorio, a meni ovčice udariše u stranu. Gruba stigla Dragića, a Radoje stekao Mionu. (Grižula, I, 7, str. 478-479) ${ }^{4}$

Nastavlja se to udvaranje - o kojemu će Miona reći: "Brižan Radoje, onizijem slatkijem riječmi me veže, lisico" (str. 491) - i u Četvrtom prizoru Četvrtoga čina, a završava obostranim pristankom, uz uvjet da i njezina majka pristane, u Trećem prizoru Petog čina, u koji je uklopljeno i Radojevo izvješće o sretnom spajanju pastirice Grube i "uzetoga” pastira Dragića:

RADOJE: Stignu Dragić Grubu i reče: “Moja si, mobne ć sa mnom!” Mati jo’ se nasmijeja i reče: "Hodite, starali se zajedno!", a Staniša reče: "Zato ću ti ja napit!" Ize mješčić i zaupi k meni: "Radoje, - reče - zdrav si!" Ja zahvalih i napih se. Mione, sada a mi?

MIONA: Uhit'mo se u dva igrat.

RADOJE: Da! Pak?

MIONA: Što maja reče, nijesam li ti rekla?

RADOJE: Da, pođ'mo ovako igrajući doma! (V, 3, str. 495)

Daleka Dijani i Kupidu, vilama i Plakiru, jer je za razliku od veze drugoga pastirskoga para, Grube i Dragića, ostala nedodirnuta vilinskim svijetom, ljubav Mione i Rada komična je i "razveseljuje", ali oni zbog nje nisu smiješni likovi. Njihova želja za stupanjem u brak i zasnivanjem obitelji nije ni u kakvu proturječju s njihovim rodom, s njihovom životnom dobi

4 Iz ovog su citata, kao i iz svih sljedećih, izostavljeni brojevi komentara i naglasci. 
i društvenom pripadnošću. Štoviše, udvaranje i prosidba i u njihovu su društvenom krugu formalizirani, podliježu određenim konvencijama, imaju značajke igre, pokatkad i obreda, s bogatim korištenjem folklornih elemenata - pjesme i plesa, pošalica, doskočica i zagonetki.

Slično bi se moglo reći i o odnosu Munua i Grube u Skupu, komediji u kojoj se, valja odmah reći, o muško-ženskim odnosima, ljubavi i braku raspravlja barem toliko koliko i o škrtosti i novcu, ako ne i više. Kao ključno pitanje i kroz njihove se dijaloge, ovdje citirane samo u izvacima, provlači pitanje o tom hoće li i kako će mežebitni budući muž uzdržavati ženu i obitelj, potom hoće li to biti odnos nadređenoga muškarca i podređene žene ili ravnopravnih partnera, a travestiraju se i petrarkistički klišeji, primjerice "ustrijeljenosti" ljubavnim pogledom:

MUNUO: [...] Ma ovo mi Grube! Ova djavolica okom strijelja. - Kmecka kćeri, kradosrca i kume ti malone rijeh, koji s njekijem imenom dođoše, rozice.

GRUBA: U tebe je ljepše ime: vjetar dunu, Munuo ga munu.

MUNUO: Rozice, ovaki kakav sam na mi ti jabučicu! Da hoćeš, Munuo tobom se munuo, ako ću ja.

GRUBA: Uzmi zveka za miris:

Sad mi pođi,

paka dođi;

majka neće,

zbogom veće!

Kad bih tvoja mlada moma, ne bih moja bila. (Skup, II, 1, str. 438-439)

MUNUO: Kud uteče, striljico? - Ava, ja i gospodar sad smo dva. Ja viđu: i mene poče srce boljet. Bogme bih ju uzeo da me hoće. (Skup, II, 2, str. 439)

MUNUO: Grube, bogme bez šale, hoć li za mene poć, ti čestita! [...]

GRUBA: Da dođem za tebe, brižan, čijem bi me hranio? ${ }^{5}$

MUNUO: Kako mala zlaca u bumbačicu bih te hranio.

GRUBA: Ava, ja mnjah da bi me dumanskijem priklami hranio. Ah oni makaruli štono dumne čine!

MUNUO: Grube, obećavam te priklami i makaruli hranit. Kontent sam, dođi za mene. $[. .$.

5 Frano Čale u komentaru uz ovu repliku ističe Držićevu vještinu u poigravanju značenjima glagola "hraniti" koji se rabi i u doslovnom smislu davanja hrane, i u smislu izdržavanja, i u smislu čuvanja, pohranjivanja (usp. Držić 1987: 470, komentar 230). 
GRUBA: Hoć mi dat priganice ali kuljena potprigana i mavasije?

MUNUO: Hoću, Grube, svega ti ću davat, i meda!

GRUBA: Vuhvence to govoriš, a pak bi me bitvom hranio, - neću za tebe! Žint me su prosili, žint, i oni, znaš, štono sirenje i sve prodava. A hoć i ti sirenje prodavat?

MUNUO: Hoću, Grube, na ti vjeru.

GRUBA: Idi, a pak ćeš govorit: "Ne tiči u to!"

MUNUO: Neću, na t' vjeru, moja lijepa Grube!

GRUBA: Da da' to sada štogodi.

MUNUO: Dat ti ću svega poslije.

GRUBA: Da, i ja ću tvoja bit poslije!

Reče Daša:

"Bit ću vaša

ako uzbude

dobra paša."

MUNUO: Grube moja lijepa, uteče li mi? - Imam dukate; ovaka mi djevojka još manjka. Strilja ti je, a što mi se veće zadražuje to mi veće srce užiže. (Skup, IV, 6, str. 454-455)

Kad se radi o ljubavnim odnosima između pripadnika i pripadnica

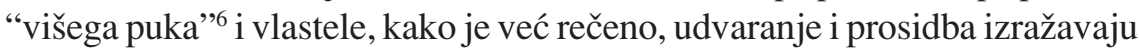
se posredno. Zaljubljenici se povjeravaju svojim "djetićima", koji prenose poruke "godišnicama" voljenih djevojaka, jer ne dolikuje djevojkama iz višega staleža da razgovaraju s muškarcima nižega staleža. Zaljubljenici se mogu izravno obraćati i "godišnicama" svojih voljenih jer je komunikacija između muškarca višega staleža i žene nižega staleža dopuštena. Zaljubljenice se pak mogu povjeravati samo svojim "godišnicama", eventualno rođakinjama i rođacima, a "godišnice" će njihove poruke ili izvješće o njihovu stanju prenijeti bilo "djetićima" voljenih mladića bilo izravno njima. U tim posredovanjima, u kojima, malo slobodnije rečeno, sluškinje i sluge riječi svojih gospodarica i gospodara prvo prevedu na svoj jezik pa tek onda priopćuju drugoj strani, a gospodarice i gospodari njihove riječi (ponovno) prevode na svoj jezik i odgovaraju na ono što vjeruju da im je trebalo biti rečeno, nerijetko dolazi do zabuna. Osim toga u njima se iz patetičnoga, gdje se od

6 Tzv. popolo grasso koji je u srednjovjekovnim i ranonovovjekovnim komunama uključivao bogate trgovce, bankare, bilježnike (usp. Držić 1987: 382, komentar 2). 
ljubavi mre, zna nerijetko prijeći u komično, pa i smiješno, gdje se i za ljubavnu bol može naći "remedijo". Šesti prizor Drugoga čina Skupa dobar je primjer posrednog udvaranja i prosidbe. Sugovornici su zaljubljeni Dobrin sin Kamilo, njegov "djetić" Munuo i Variva, "godišnica stara Skupova":

VARIVA: [...] Kamo gospodaru, zli glasi: Andrijanu vjeriše za tvoga dunda, Zlatoga Kuma.

KAMILO: Ajme, Variva, ubode me! Ajme! [...] Munuo, pomozi me! Variva, ajme, moju Andrijanu za moga dunda! Nije veće remedija!

MUNUO: Gospodaru, kako nije remedija? Jes remedijo; svemu je remedijo neg samoj smrti. Ne desperavaj se! [...] Rijet ću da si namuran na tu djevojku i, kako si čuo da je su ovako vjerili, da se s' ti razbolio i da hoćeš umrit. [...] Ako uzbude još od potrjebe, rije' ću da je ona tebi, a ti njoj, vjeru dala i da je od toga svjedočba.

VARIVA: Ja sam, Munuo, svjedok od toga, ja ću svjedočit.

KAMILO: Ah, draga Vare, u Andrijani sve stoji.

VARIVA: Ne brini se, Kamo; Andrijana će tvoja bit.

KAMILO: Ajme, da to će bit, a nije sad moja?!

VARIVA: Sada je tvoja: meni je rekla er bi prije u more skočila neg bi za inoga neg za tebe pošla.

KAMILO: Ajme, je li koji način da se š njom govori?

VARIVA: Ja ću za tebe š njom govorit. [...] Ja znam nje ćud i kako te dobro hoće. $[\ldots]$

KAMILO: Vare, reci joj: "Andre, sad je brijeme da tvoga Kamila ne umoriš!" Reci joj: "Znaj er bez tebe ne mogu nikako živjet; u tebi stoji život moj i smrt moja!"

VARIVA: Hoću, Kamo. Pođite, da oni zlostar ne bi izišao.

KAMILO: Vare, da sam ti priporučen! (Skup, II, 6, str. 442-443)

Obuzet ljubavlju, i oduzet s te obuzetosti, s uzdahom "ajme" ili "ah" u gotovo svakoj replici, zaljubljenik Kamilo naginje na smiješnu stranu. Njegovo ponašanje i njegov govor, istina, nisu u potpunoj “opreci socijalno uvjetovanim normama" (Fališevac 2007: 107), što je razlikovno obilježje "smiješnoga", ali su nedvojbeno u još manjem skladu s njima.

Skup je komedija u kojoj "naracija", da se vratim na distinkciju Jill Levenson, prati usklađene aktivnosti niza likova na sprečavanju društveno nepoželjnoga braka između Zlatoga Kuma, starca smiješnoga u prihvaćanju sestrine ideje o stupanju u brak unatoč poznim godinama, i Andrijane, lijepe, mlade djevojke, premlade za očeva vršnjaka i Kamilova ujaka Zlatoga Ku- 
ma. Usporedo prati, također usklađene, aktivnosti na uklanjanju prepreka društveno poželjnom braku mladića i te djevojke, a one su kombinacija nesklonih roditelja (Andrijanina oca Skupa i Kamilove majke Dobre) i suparnika, onoga starca posve neprikladna za ulogu koju je prihvatio, ali s jakom potporom dvoje netom spomenutih roditelja, ključnih autoriteta u toj situaciji. Dakako da onda brak, uz novac i škrtost, u toj komediji mora biti i jedna od središnjih tema koje se provlače kroz "retoričku raspravu". Iza te rasprave što se vodi na pozornici - a ima u njoj i smiješnih i komičnih, ali i posve razložnih crta, napose u Dživa - nazire se na kraju srednjovjekovlja i u ranome novovjekovlju aktualna rasprava između zagovornika starih i novih nazora o braku. Pojednostavljeno rečeno, stari zagovaraju podređenost žene mužu, a novi ravnopravan, partnerski odnos (usp. Janeković Römer 1994. i 2008: 552-553).

Kao što je u Dundu Maroju središnje pitanje komu će pripasti mladi dubrovački trgovac Maro, rimskoj kurtizani Lauri, ili dubrovačkoj djevojci Peri, tako je u Skupu središnje pitanje komu će pripasti mlada djevojka Andrijana - mladom Kamilu ili starom Zlatom Kumu. I oko tog se pitanja zaista vodi nekoliko rasprava. Sve bi bilo jednostavno da je samo Skupova škrtost prepreka na putu sjedinjenja Kamila i Andrijane. Tu su međutim ključna i posve oprečna shvaćanja braka koja iznose s jedne strane Dobre, dundo Niko i Zlati Kum, a s druge, dakako, dvoje mladih, Kamilo i Andrijana, "godišnice" i "djetići” te razboriti Dživo. "Retoričku raspravu" o braku otvaraju zapravo Variva i Grube već u Prvom prizoru Prvog čina komentarima Skupove najave Andrijani da će ju dati za ženu "njekomu zlostaru koji vele da je bogat" (Skup, I, 1, str. 431). Komentari se ne odnose samo na Andrijanu, koja je već "obećala Kamilu" (str. 432), nego uopće na prevelike dobne razlike u braku. O braku, ne samo onom koji se njemu predlaže, u Desetom prizoru istoga čina mnogo opširnije raspravljaju Zlati Kum i njegova sestra Dobre. Razgovor se njihov, o kojem Dobre kaže da ga je namjerno povela na trgu, daleko od znatiželjnih ukućana, sastoji od dva dijela. U prvom se Zlati Kum opire njezinu prijedlogu da se oženi, pozivajući se na svoju poodmaklu dob i nemoć koju ništa ne može prikriti. U drugom dijelu, ključnom i za "naraciju", brat i sestra izražavaju posve oprečne sudove o mirazu i njegovu utjecaju na odnos supružnika. Dobre bi dovođenjem bogate žene s mirazom uvećala financijsku moć cijele obitelji, onemoćali bi Zlati Kum dovođenjem siromašne žene bio u odnosu na nju barem financijski nadmoćan, a ne da ona, pozivajući se na miraz koji je donijela, bude njemu nadmoćna. Evo dijela njihove rasprave: 
DOBRE: [...] Ja ti sam našla djevojku s prćijom od vele tisuć dukata.

ZLATI KUM: To mi i u kuću da', da mi govori: "Što? Kupila te sam, prćiju ti sam donijela veću neg ti valja svoj parentati imanje! A hoću ovo, a hoću ono”, spendze da im carova riznica ne bi dosta bila! Dobre, ni mi o ženi govori, ni mi uspomenuj tej velike prćije: žena nije za mene, od prćije ne imam potrjebu.

DOBRE: Zlato, kako si ti od potrjebe koji se zlato zoveš, tako i zlato nigda nije naodmet. A nije ni toliko koliko se govori od bogatica s velicijem prćijami. Sestricu tvoju, moje zlato, kontenta'. [...]

ZLATI KUM: Pokli je tolika ta tvoja imadžinacijon, kontent sam; ma neću neg kugodi ubogu djevojku. Neću gospođa u kući, hoću djevojku kojoj ću ja gospodar bit, a ne ona meni. Ja ne imam potrjebu od imanja.

DOBRE: U ime Božije! A mi da ti djevojku nađemo od dobre kuće; a o prćiji, ili bud' ili ne bud', da, ne misli!

ZLATI KUM: Jes u ovoga tvoga susjeda ovdi, dobra čovjeka, kći djevojka kostumana.

DOBRE: Skupova kći? Ubog je odveće!

ZLATI KUM: Velim: bogatu neću! [...] Za nju mi je Skup jedan dan govorio i spovidio mi je svoje uboštvo, i priporučio mi se. I ja mu odgovorih kako se zaonda ne mišljah ženit i ako bih se odlučio ženit, imao bih ga na pameti. I, za rijet ti, srcem ljubim onu kuću; djevojku sam tu vidio: oko mi ljubi nje krv. (Skup, I, 10, str. 437-438)

Ako su ostarjeli brat i sestra komični, pa i smiješni, u djetinjasto tvrdoglavu nagovaranju i protivljenju, nametanju i odbijanju, u starčevoj "filozofiji braka" nema mjesta za komiku i smijeh, nego samo za izravno i bez imalo uljepšavanja postavljeno pitanje o tom tko će komu u braku biti gospodar. Ni o kakvoj ljubavi i poštovanju, a kamoli o partnerstvu, ovdje se ne razmišlja, a staračka požuda što izbija iz posljednje citirane replike bila bi smiješna da zbog izbora riječi i sugeriranoga tona kojim se one izgovaraju nije groteskna. U Desetom prizoru Trećega čina Zlati Kum dokraja razvija tu svoju "filozofiju", objašnjavajući korist koju će iz takvog braka imati i Grad, a dodatnim argumentima potkrepljuje i svoj izbor siromašne djevojke za ženu:

ZLATI KUM: [...] Na ovi bi način Grad bolje stao: bogati bi uboge počtapljali; tako bi se Grad i uzdržao i mantenjao u dobru bitju u vječna brjemena, a ne uboštvo, kako grinja, konsumavalo građane i Grad. [...]

Bogati scijene, okoristovat se će kad uzmu ženu s velikom prćijom, a ne misle što pak provaju, er žena od velike prćije hoće i velike spendze. I ako joj muž ne da te spendze tolike činit, ima pakao s utra i večer uza se, koji ga martoriža ne pristajući 
mu govoreći: "Ne daš mi što mi je od potrjebe; a nijesam li donijela da mogu imat moju potrjebu? A što misliš da ti će to moć bit? Donijela sam ti već neg ti valjaš”, i tacizijeh riječi. [...] A kad bogat uzme djevojku uboga oca a dobra, i dobre matere, gdje je imposibilo da i kći njih nije dobra, ne ima toga pakla, ma ima drugu ka mu je oblegana, koja nije uzrasla u oholasti, neg u omiljenstvu, koja mu je poslušna, koja poznava dobro koje ima da ga od njega ima; nije luda da želi od razblude i što jo' nije od potrjebe, uzdavši se u prćiju koju je donijela, ma je razumna, diskreto pita u gospodara svoga potrjebu svoju, koji za za nje diskrecijon, veće joj dava neg pita. (III, 10, str. 449-450)

Prije ovoga primjernog dijela "retoričke rasprave" na temu braka, odnosa između muža i žene te odnosa moći u braku - pri čemu je Skup skriveni slušatelj i komentator zadovoljan što iz tih riječi može pouzdano zaključiti da Zlatomu Kumu nije do njegova "tezora" nego do, recimo tako, milostivoga a ničim ugrožena ili osporavana vladanja nad zahvalnom, poslušnom i skromnom ženom - u Četvrtom prizoru Drugoga čina Skup i Zlati Kum već su postigli dogovor o uvjetima pod kojima će se sklopiti brak između bogatoga starca i siromašne djevojke, uz ono glasovito ponavljanje ključnoga uvjeta "bez prćije" (str. 441). Dogovor je kratak jer Skup Andrijani ne želi dati miraz eda zadrži novac za sebe, odnosno za škrtost koja njime vlada, a Zlati Kum ne bi ni htio primiti miraz kako se žena ne bi mogla pozivati na njega i zahtijevati barem minimum financijske neovisnosti i zadovoljavanja vlastitih "potrjeba".

Najvažniji segment "retoričke rasprave" u komediji što na tom mjestu kao da prelazi iz komedije karaktera, kojoj bi Skup prema uvriježenoj klasifikaciji komičkih žanrova pripadao, u komediju običaja, ${ }^{7}$ nedvojbeno je dijalog Dobre i njezina prijatelja Dživa. Vodi se u Prvom prizoru Trećega čina, počinje razrješavanjem nesporazuma oko toga tko se vjerio s Andrijanom, Kamilo ili Zlati Kum, pa preko pitanja o tom u kojoj su dobi mladići spremni za ženidbu dolazi do tada aktualne - a s obzirom na to da je "[k]omedija prikazana u Saba Gajčina na piru" (str. 429) i izravno angažirane u korist nevjeste i njezine ravnopravnosti u novoj obitelji - polemike o odnosima muževa i žena u starim i novim brakovima i o tom je li nevjesta "godišnica" ili "gospođa" u muževoj kući:

DOBRE: Rasuta! Vjerio! Ona djetetina, još mu usta mlijekom vonjaju! Za njega je žena!Neće mi u kuću! [..]

7 O komediji, komičnom i komičkim žanrovima usp. Pavis 2004: 191-197. 
DŽIVO: Zašto, Dobre? Imaš onoga jednoga sina, a imaš svega milos Božiju. Koje će zlo bit da t' nevjestica u kuću dođe, od koje ćeš zabavu imat i odmjenu u sve kućne posle?

DOBRE: Odmjenu u kućne poslu?! Nemoj mi, Dživo, spovijedat što su sadanje nevjeste! Od sadanjijeh nevjesta nije neg spat do podne; a kad se ustane, dvije djevojke nijednoj nijesu dosta da ih sapinju i oblače. A kad se obuku, jedva do objeda mrdajući oko glave njeke čičke od kosa zavijajući i pri zrcalu [...] čerse, zle česti, a pak se u crkvu dođe, a mise se sve svršile. (Skup, III, 1, str. 445)

Slijedi, prekidana samo kratkim Dživovim upadicama poput "Mlados je taka!", Dobrina tirada protiv nevjesta, naviještena zapravo već Prologom, u kojemu se pak u ime "mladica" prekoravaju svekrve jer da "vazda karaju, vazda psuju, vazda nemirne" (str. 430). ${ }^{8}$ Iz Dobre izravno progovara konzervativno, ili barem tradicionalističko, shvaćanje obitelji kao hijerarhijski ustrojene osnovne društvene zajednice u kojoj su muškarci nadređeni ženama, a stari mladima. Diči se time što su ona i njezine vršnjakinje bile predane samo kućnom radu - "dokle bi on [njezin muž, nap. B. S.] ustao, dva vretena bih naprela" (III, 1, str. 445) - a za pojmove poput slobodnoga vremena, dokolice, igre, zabave, užitka u njezinu diskursu i svjetonazoru što ga on gradi nema mjesta. ${ }^{9}$ Iz nje onda, posredno, dakako, progovara $\mathrm{i}$ shvaćanje povijesti kao degenerativnog procesa, procesa nestajanja "pravih" vrijednosti, raspadanja društva, opadanja morala. Dobri nasuprot stoji razložni Dživo, zagovornik novoga doba, promjena u društvu i braku, koji će se glasovitim monologom "Moj Bože, čudan ti je animao čovjek” (str. 455), u Osmom prizoru Četvrtog čina deklarirati kao primjeran držićevski “čovjek nazbilj”. ${ }^{10}$ Žena je mužu, drži Dživo, ravnopravan partner, ali i ta

8 O odnosu prologa i Dobrinih kritika na račun mladih nevjesta, kao i o njezinu konzervativnom svjetonazoru, ali i o njezinoj tiradi i o nekim tematski srodnim tiradama i monolozima kao "prilozima za povijest svakodnevnog života" u Držićevu Dubrovniku, usp. npr. Čale 1987: 9-168; za ovu temu posebno str. 113-114.

9 O slobodnom vremenu, dokolici, igri, zabavi itd. kao ključnim kriterijima razlikovanja društava i kultura, pa i o ulozi kazališta u tom razlikovanju, informativno piše antropolog (i teatrolog) Victor Turner 1989: 35-125.

10 Za dio tumača, Frana Čalu primjerice, Dživo je i lik u funkciji "iznošenja pjesnikova svjetonazora" i tumačenja "piščeve istine o svijetu" (Čale 1987: 115). Slobodan P. Novak, naprotiv, ne pridaje ni izbliza toliku važnost Dživu i njegovu udjelu u "retoričkoj raspravi”. Ustvrdivši da je u Skupu, za razliku od Dunda Maroja s Pometom kao dramatičarovim alter egom, izostalo "tematsko i ritmičko žarište", on Držića vidi isključivo u naslovnom liku: “Zato Držićev glas i kada govori kroz usta Dunda Dživa [...], ne uspijeva ovladati i ritmom igre. Taj glas je tematski, on dolazi izvan prostora igre, pa zato i ostaje izvan njega. U rukopisu Skupa piščevo tijelo igra zato samo u jednom liku, u liku Skupa" (Novak 1984: 110). 
ravnopravnost, kako se čini, ima određenu cijenu i nije svakoj nevjesti dostupna:

Ne daju ih [kćeri, nap. B. S.] oci za godišnice s tolicijem prćijam muževom, ma da su gospođe i da zapovijedaju. Ja mojoj ne dam da toliko s jutra ustaje; drago mi se je u odru s njom ovako porazgovorit ujutro. Komu je žena draga, i sve mu je drago što čini. A jeda su nam robinje? Godišnice za ognjište, preslice za kudjelju, a vladika da zapovijeda u kući! [...] Vi ste u ono brijeme bile kad se je u bortijeh hodilo; a ove su u ovo kad se i svila dere, i dobro da se dere, er jest od šta. (III, 1, str. 445)

Kao i u primjerima Skupa i Zlatoga Kuma Držić i u Dživovu primjeru njegov obol "retoričkoj raspravi" ne iscrpljuje u samo jednom prizoru ili samo jednom monologu. Tako u već spomenutom Osmom prizoru Četvrtoga čina, Dživo u raspravi s Nikom, "dundom Kamilovim”, raspravi koja će se zbog krutosti i mrzovolje Nikove izvrgnuti u svađu, zagovaranje novoga odnosa između muža i žene širi na odnos oca i sina te na pravo mladića da stupi u brak i zasnuju obitelj po svojoj volji, a ne pod prisilom očeva ili stričeva autoriteta. Polazeći od Kamila i braneći njegovo pravo na brak s Andrijanom, Dživo se upušta u općenito razmatranje na temu dobrih i loših obiteljskih pa i društvenih običaja te ljubavi i povjerenja koje bi trebale zavladati tamo gdje u Nika i njegovih istomišljenika vlada sila:

Oci nerazumni zlijem guvernom, nemirni s bata, koji palicom, ne ljubavi od oca alevaju sinove, učine da im su sinovi ne sinovi ma neprijatelji. I na to ih pravda Božija osudi er sinove valja alevat kako sinove a ne kako robove. (str. 456)

O tom kako se "retorička rasprava" privodi kraju, što su završne Dživove riječi, njegova pouka i poruka pirnicima, napose mladencima i njihovim obiteljima - a imamo dobrih razloga pretpostaviti da je baš Dživo jedan od posljednjih govornika, ako ne i posljednji govornik, koji će u ime družine pozdraviti gledateljstvo - možemo, nažalost, samo nagađati te svoja nagađanja, poput Mihovila Kombola, uobličiti u nadopunu Skupa. ${ }^{11}$

U Arkulinu, sljedećoj komediji relevantnoj za temu bračnog života - i predživota - Držićevih likova povezuju se dvije Greenblattove etape, naime uvjetno rečeno udvaranje, zapravo spletke oko sklapanja braka, te sam čin vjenčanja, ali s Negromantom preobraženim u Arkulina kao mladoženjom, a Arkulinom kao uzetim promatračem vlastita vjenčanja. U jedinom sačuva-

11 Kombol je završne riječi, međutim, dodijelio Munuu. 
nom prizoru Prvoga čina Arkulin je dijelom s vlastitoga stajališta, dijelom sa stajališta Vlaha Kučivrata, koji ga svojim komentarima okrutno, čak i vulgarno ismijava, određen kao škrtac, hvalisavac i, što je ovdje najvažnije, stari zaljubljenik. Kučivrat će to izreći jednom rečenicom - "Stara se je klada užegla" (Arkulin, str. 536) - a Arkulin mnogo razrađenije, posve neprimjereno i nekritično, što ga onda i čini prikladnim objektom Kučivratova ismijavanja i gledateljskoga smijeha. Naime, nakon što odrecitira šest stihova u petrarkističkoj maniri, u kojima svoju ljubljenu (udovicu Ančicu, po svemu sudeći ne baš ljepoticu a ni osobito čednu) naziva "gizdavom rozicom" i "diklicom", a sebe njezinim "robom" i "slugom", Arkulin se sam sebi divi kao čovjeku oplemenjenom ljubavi, ali istodobno uporabom neprikladna izraza "pljujem verse" samoga sebe i demantira: "Nut što ljubav čini! Amor con che miracolo fai, da prije ne znah što je veras, a sad pljujem verse. Amor, el tuo dolce liquor, kako med pčelicu u slasti sve stavlja" (ibid.). Komičnim ga napose čini to što iz petrarkističkoga klišeja patnje zbog neuzvraćene ljubavi, koji primjenjuje na sebe i Ančicu - "Ma ti, krudela rubella de amore, čemu si krudela? Što hoć od mene?" (str. 537) - prelazi u posve prizemno, povrijeđenom taštinom prožeto psovanje Ančice, sada već "kurvine kćeri”, i prijetnje nožem ("pestulezom”):

Ma kad me umoriš, poslije ti će žao bit; jošte ćeš, kučko, za mnom i proplakat, et dopo morte aiuto porzerai al tuo Arkulino, - kad, kučko, bude zaludu i kad ti bude mala har, i kad, kučko jedna... Ja te ću... po svetoga Arkulina, moje ime! Ne budeš bez mene umrijet, da je zdrava ova pestuleza! (ibid.)

Za razliku od Skupa, gdje likovi imaju vremena zastati i upustiti se u "retoričku raspravu", u Arkulinu kao da im se žuri privesti "naraciju” kraju. Uostalom, pet činova Arkulina, s nevelikom lakunom na početku (str. 535-556), zauzima za trećinu manje stranica od pet činova Skupa, s vjerojatno podjednakom lakunom na kraju (str. 429-461), a scenske radnje, koja uključuje i mačevanja, i "jurišanje" na kuću, i gađanje napadača kamenjem s gornjega kata, i Negromantov trik s nestajanjem Arkulinove kuće, i Kučivratovo nošenje onemoćaloga Arkulina “na krkače”, i uprizorenje obreda vjenčanja, u Arkulinu ima više negoli u Skupu. Staračka Arkulinova požuda bez mnogo argumentacije traži put do ispunjenja, bilo u braku, bilo u priležništvu s Ančicom, a od očitovanja te žudnje u već spomenutom jedinom sačuvanom prizoru Prvoga čina do Arkulinova ulaska u kuću, nakon što je uzet, nepriznat i nemoćan da bilo što poduzme u Drugom prizoru Petog čina svjedočio izvedbi obreda vjenčanja Ančice sa svojim dvojnikom, brzo 
prolijeću tri čina, kako je rečeno, užurbanih Arkulinovih nastojanja da dođe do Ančice. Mnogo aktivniji od ostalih starih i mladih zaljubljenika u Držića i drugih eruditnih komediografa, on poseže za raznim sredstvima postizanja svojega cilja, od "dunižanj[a] nje pod kućom" (str. 536) do organiziranja provale u tu kuću i otimanja nevjeste, od pokušaja pridobivanja Negromanta da mu svojim umijećem postigne da mu "jedna moroza dođe doma" (IV, 3, str. 547) do prijetnji i psovki. Cijelu zavrzlamu oko prosidbe u nekoliko rečenica sažima Tripe Kotoranin kad pridobiva Negromanta za svoju, Viculinovu i Marićevu nakanu da prevare Arkulina:

Ovi dobri dijeci imaju udovicu u kući, zlu pečenicu, er se hoće udat, a nije prćije, misser mio, - dukate velike pitaju, a nije ih! Arkulino de altro canto si xe inamorao di essa, et senza dote non la vol per sua consorte, za domaću, ma ju hoće za hotimicu, et per forza. Zato molimo la signoria vostra da učiniš da rečeni, misser mio, Arkulin Arkulinivić vazme Ančicu bez prčije i da joj kontradotu učini. [...] Ja rekoh kako umjeh. (IV, 5, str. 549)

U dobrom dijelu komedija u kojima "naracija" prati svladavanje prepreka na putu do ispunjenja ljubavi, vjenčanje se ugovara, utanačuje i navješćuje, ali tek u Pfisterovu "tercijarnom vremenu". U komedijama gdje "naracija" rješava, da ponovim riječi Dunje Fališevac, "probleme nevoljnog braka", vjenčanje prethodi početku prikazane radnje. U Drugom je prizoru Petog čina Arkulina međutim uprizoreno vjenčanje "in pubblico", kako kaže Marić, "da poslije, misser mio, kao djeca ne počnemo se poricat" (str. 551). I formule koje se pritom izgovaraju zacijelo bi mogle poslužiti kao građa za povijest svakodnevnog života:

KANDŽILIJER: Čuj, veliki i mali, er Arkulo Arkulinović uzima za ženu [...] i za svoju vjerenicu ledžitimu [...] Ančicu, kćer Skočikimka Lopuđanina. [...] Sada, messer Arkuline Arkulinoviću, jesi li kontent [...] uzet Ančicu za tvoju ledžitimu spozu?

NEGROMANT: Misser scì jesam! [...]

KANDŽILIJER: A ti, Ančice, jesi li kontenta uzet za tvoga ledžitima spoza i vjerenika Arkulina Arkulinovića? [...]

ANČICA: Jesam! [...]

KANDŽILIJER: Sada, misser Arkulino, prije nego joj ruku tokaš, triba je da joj kontradotu učiniš. [...] Tisuću perpera, kako si obećao. [...]

NEGROMANT: Kontent sam. [...]

MARIĆ: Kandžo, jes' li upisao?

KANDŽILIJER: Upisao sam! 
NEGROMANT: Sad te prstenujem, moja Ančice draga; a sada te celovom della pace celivam. I hod'mo veće put kuće. (V, 2, str. 551-553)

Komika, sjajna komika u ovom prizoru proizlazi dakako iz činjenice da Arkulin, stojeći postrani nepokretan, isključen, nepriznat i neprepoznat - jer čak i Kučivrat, koji se s njim na plećima vratio nakon neuspješne potrage za liječnikom, prelazi u skupinu okupljenu oko "Kandžiljera" te kao svojega gospodara prepoznaje i priznaje Negromanta - gleda kako ga žene za Ančicu, kako mu, a škrt je, uzimlju pozamašnu "kontradotu", kako svi ulaze u njegovu kuću, a on nepokretan ostaje napolju, i sve to prati povicima čuđenja, očaja i, napokon, rezignacije:

Ajme, vjerenicu ledžitimu! [...] Ajme, koji je to Arkulin drugi?! [...] Ajme, ja sam uzet! U sni ja vidim moje zlo! [...] Sada zlo, sada plači, nevoljni Arkuline! [...] Misericordia, mojom kućom njetko zapovijeda! [...] Ajme, smrti, što me ne umoriš, da ovolike tuge ne gledam prid mojijem očima? [...] Ovo, meschino me, nije san! Factus sum derisio gentium et domus mea desolata facta est preda di cani e di ribaldi! Misero Arkulino, che speri ormai? [...] I smrt se je rebelala od zločestoga mene $[\ldots](\mathrm{V}$, str. 551-554)

U izvedbi su Arkulinova izdvojenost i osamljenost te status nemoćna promatrača ispunjenja vlastite sudbine još jače nego li zagradama u koje priređivači teksta stavljaju njegove replike naglašeni prostornim razmakom između njega i ostalih likova, koji svi sudjeluju u "njegovu" vjenčanju s Ančicom, a njegova sumnja u zbiljnost svega što vidi, pa i u sebe sama, u vlastiti identitet, poziva na neprekidne vježbe u tumačenju. ${ }^{12}$

12 Tako za tumačenju tog prizora iz psihoanalitičkoga očišta usp. Čale Feldman 2012: 55-77. Evo samo jednog kratkog izvatka iz te studije: "Za razliku od pitanja ženine nevjere što dominiraju u Plauta i Molièrea, Arkulin je [...] u cijelosti premrežen upravo komički dočaranim okolnostima sklapanja bračnog sporazuma kao poslovne transakcije, koju u ime našega protagonista obavlja 'onostrana', to jest ovdje eksplicitno kazališna figura, obznanjujući svojom opsjenarskom djelatnošću baš ono do čega je i Lacanu toliko stalo, pokazati naime da je simbolički poredak, kao neizbježni okvir regulacije ljudskih odnosa, fiktivna, kulturna konstrukcija ovjerena jezikom, koji međutim proizvodi stvarne učinke [...] upravo onako kako i Arkulin, koji nije sam pogodovao bračnoj pogodbi, nego je njezinu fiktivnom iskazu nazočio u ulozi nevoljkog gledatelja koji u fikciju ne može intervenirati, ipak na kraju bude oženjen Ančicom, samo ne pod svojim, nego pod uvjetima svojte [...]" (str. 72).

S druge strane, prizoru vjenčanja može se pristupiti i sa stajališta Austinove teorije "govornih činova", odnosno performativa jer "[k]lasičan Austinov primjer performativa jest iskaz 'Uzimam' izrečen na obredu vjenčanja” (Blečić 2015: 226). Uzme li se u obzir da u vjenčanju Arkulina, protiv njegove volje, zamjenjuje Negromant, svi pristanci i sva obećanja izgovorena 
Napokon, prisutna je u Držićevim komedijama i treća Greenblattova etapa. "Pokora" zbog "nevoljnoga braka" u središtu je komedije Tripče de Utolče, a o "nevoljnom braku" staroga muža i mlade žene posredno je riječ i u Noveli od Stanca. Jedno je od češće citiranih mjesta iz Stanca razgovor u Trećem prizoru, iz kojega proizlazi da prevareni stari "vlah" baš i nije posve nedužna žrtva obijesnih dubrovačkih "noćnika":

STANAC

Gdi bih se po srjeći i ja ovdi pomladio!

[...]

Što bi Miona dala, domaća mo'a mila!

DŽIVO

STANAC

Bogme bi uzigrala!

Ah, rada t' bi bila,

gdje je ona hubava mladica a ja star.

DŽIVO

STANAC

Bila bi ‘oj zabava.

Bogme bi 'o' bilo u har!

er ne bi naprijeda uza me plakala

grijav peču leda, ma bi mirna stala.

(Novela od Stanca, str. 273)

Dalje se o Stančevu braku ne razgovara, ali dvostih s bljeskovito danim tužnim prizorom iz bračnoga kreveta kazuje mnogo više od razrađene tirade na temu braka starca i djevojke.

Na kraju, prije završnoga kratkog osvrta na komediju Tripče de Utolče, odnosno Mande, valja ponoviti ocjenu koju je Dunja Fališevac iznijela u studiji Rezignirani renesansni “junak" Tripče, ali ne na već citiranom mjestu, nego nešto ranije:

Komedija je komponirana na trima fabularnim linijama, odnosno na trima zapletima, pri čemu sve fabularne linije problematiziraju muško-ženske odnose, odnosno probleme braka, nevjere i bračnog trokuta. Dominantna je fabularna linija: Tripče - Mande - Mandin ljubavnik, mladi Dubrovčan. Druga je fabularna

na tom vjenčanju izvrsni su primjeri Austinovih "neposrećenih" iskaza. Prihvaćajući Ančicu za svoju "ledžitimu spozu", unatoč tomu što nije sudjelovao u vjenčanju i što nije izgovorio ni jednu riječ koja bi ga obvezivala i koja bi vjenčanje učinila legitimnim, Arkulin međutim "neposrećeni" iskaz pretvara u "posrećeni". 
linija ona koja prezentira radnju koja se događa na relaciji: Pedant Krisa - Mande - Džove. [...] Treća je fabularna linija ona na relaciji: Lone - Mande - Kata [...] Navedenim linijama može se pribrojiti i epizodna fabularna linija: Mande - Turčin (Fališevac 2013: 118-119).

Tripče de Utolče ne može se, dakako, dovoditi s bilo kojom Držićevom komedijom u vezu u kojoj su, pretpostavljamo, bile izgubljeni Pomet koji se zbiva u Dubrovniku i njegov, uvjetno rečeno, rimski nastavak Dundo Maroje. Problemski međutim Tripče jest nastavak Skupa jer u njemu se na primjeru mlade Mande i ostarjeloga, nemoćnog, pijanog Tripčeta bjelodano pokazuje u kakvu se, grinblatovski rečeno, "pokoru” za oboje pretvara brak između neprimjerenih partnera. U Drugom prizoru Trećega čina publika, gledajući Kotor iz Dubrovnika, ili Kotor u Dubrovniku, ili, možda najbolje rečeno, Dubrovnik kao Kotor, a Dubrovčane s njihovim manama kao Kotorane, kao druge,$^{13}$ gleda sliku izvrnuta svijeta. Tripče je zaključan u kući, u prostoru obiteljskoga života kojim dominiraju žene, a Mande je na ulici, odnosno trgu, u prostoru javnoga života kojim dominiraju muškarci. Mande je u muškoj, Tripčetovoj odjeći, a Tripče je očito u donjem rublju - "Bez haljina sam" (D, str. 515), požalit će se u Sedmom prizoru Jeđupki - te će se poslije obući u Mandine haljine. Umjesto konvencionalne podoknice u kojoj mladić s ulice ili trga upućuje ljubavne riječi djevojci na prozoru ili balkonu, muž s prozora ženi, a žena s ulice mužu upućuje psovke i pogrde:

TRIPČE: Ah, Manda, ti li si? Na solacu si bila? Drago mi je, er umiješ dobra bremena uzet izvan svijeh ostalijeh dobrijeh žena.

$M A N D E$ : Tripče, što su te riječi? Ali mniš da sam na kom zlu bila?

TRIPČE: U tebe je ključ! Ti si veće gospođa od kuće i sama od sebe: hodi na solac kud ti od volje dohodi. Tripče je zatvoren u tamnici, žena mu sama u mušcijeh haljinah tance, s tuđijem ljudmi tance izvodi.

MANDE: Brižna, što su te riječi? Ali si jošte pjan? Mnim da si pjan nješto snio. TRIPČE: Ja sam pjan, ja sam mahnit. Pođ' išti drugu kuću.

MANDE: Kamo ću it, sramoto moja? Vazda me si ti sramotil.

TRIPČE: Zna' ćeš, kučko jedna, ribaodo, zla ženo, kojijem putom greš i ke igre igraš! Neka ti dođu bratja, po ke sam poslao.

13 Erich Segal ustvrdio je u knjizi Rimski smijeh. Plautova komedija da je glavni razlog zbog kojega su rimski komediografi svoje likove odijevali u grčke halje, davali im grčka imena i radnju smještali u grčke gradove bio taj da Rimljanima poruče kako su zapravo oni "izopačeni kao Grci” (usp. Segal ²1987: 23-24). 
MANDE: Tripče, što je to? Što su te stvari? Zaklinam te živim Bogom, otvori mi kuću, ne sramoti me, er se sad zaklah, ter će rit da me s' ti zaklal, ter ti će glavu usić.

TRIPČE: Zakolji se, udavi se, objesi se! Neć ti veće u moju kuću; kurbe neće u moju kuću!

MANDE: Jaohi meni! Da ti Bog prosti! Ja veće idoh, ter se zaklah. Moja duša da ti dobrom plati ovu sramotu na onomu svijetu!

TRIPČE: Kolji se, zla ženo, a odavna se si zaklala tijem putem hodeći. [...]

MANDE: Jaohi meni! Brižna ja, sjetna, tužna ja, što ću sada? Kamo ću sada? Ja ostah ružna, osramoćena! Brižna, iznutra se je zatvoril, ne mogu uljesti u kuću; po' ću opeta k vratom vrnuti, jeda me kako srjeća pomože, da otvori romazin iznutra, a u mene je ključ od brave. Sjetna Mande, ljubovnika stekla, a brižna u ljubav zašla! (str. 512-513)

Zahvaljujući "anastrofi" u Petom činu, sve ove riječi dakako gube na težini i postaju tipično komičko pretjerivanje koje se pretvara u ono glasovito kantovsko "ništa". Nitko se nije "zaklao", nitko se nije "udavio", nitko se nije "objesio", nikomu neće "glavu usić", nitko čak nije ostao ni na ulici, ni bez obitelji, nijedan se "nevoljni brak" nije raspao. U "anastrofi" se naime iz prizora u prizor, kadikad i na začudan način, kao u nekoj hitnji, uređuju muško-ženski odnosi u svim "fabularnim linijama". Svi "lomovi" i "krize" od kojih su počele te male "društvene drame" barem se privremeno razrješuju "reintegracijom" zavađenih strana (usp. Turner 1989: 142-148).

Tripče nije Mandinoj "svojti” dokazao ženinu nevjeru i predao se "Me rendo, ja sam izgubio, vi ste pravdu dobili" (V, 6, str. 526) - te još izmolio oprost i pripravan je nakon pozdrava s publikom pokajnički ući u vlastitu kuću iz koje ga je dosjetljiva, iz očaja dosjetljiva Mande nakratko izbacila.

"Ludi Krisa", zaljubljeni pedant, nije prevario ženu Džovu s Mandom, nego se, naprotiv, nakon duga vremena izbjegavanja seksualnih odnosa u braku, uz neuvjerljive isprike kao što je "Stomak me boli!", "junak učinio" s njom u zamračenoj sobi Anisuline kuće te prenuo iz zanosa: "In fine, ljubav se je htjela narugat danas mnome, ma veće se ne bude mnom rugat" (V, 3, str. 523).

Stari pohotnik Lone de Zauligo, također u zamračenoj sobi Anisuline kuće, nije obljubio ni Mandu ni njezinu sluškinju Katu, nego je bio izvrgnut ruglu, uhićen, utamničen i stavljen pred izbor: ili "da pet godišta stoji u okovijeh u tamnici", ili "da plati préiju Kati [...] pecat librica" (V, 5, str. 525). Izabrao je naravno platiti, ali ne samo to, nego je u Kati prepoznao 
svoju vanbračnu kćer te je i on - $\mathrm{u}$ istoj sobi iste Anisule, koja tako postaje svojevrsnom protuljubavnom terapeutkinjom, a zamračena soba u njezinoj kući mjestom pročišćenja - ušao u proces izlječenja od neprimjerene ljubavi te se i on osvijestio: "I ljubav veća manju pridobi. Mandu zaboravih pri ljubavi od kćere" (V, 6, str. 526).

Za Turčina Mahmuta pak koji pred Mandinu kuću dolazi kao još jedan komični zaljubljenik, na kojega u izgubljenom početku komedije Kerpe "ktijaše puškom strijeljat" (D, str. 525) i koji pokušava jadikovati u petrarkističkom ključu, s pokojim turcizmom - "Svitla zvizdo danico, pomiluj, rob tvoj umire! Aman da znam da mi glava otide, uljezoh gori s tebi!" (V, 4, str. 524) - otkrije se da je Mandin oteti brat Frančesko.

Ipak, sve uvrede, prijetnje i kletve koje likovi u ovoj komediji jedni drugima prije pomirenja u "anastrofi" upućuju, a njih ovdje zaista ne manjka, mišljene su i izgovorene, i ne mogu biti dokraja zaboravljene. Gorak okus ostaje za njima, kao što gorak okus, neka mi bude dopuštena malo slobodnija usporedba, ostaje i za svim onim pogrdama koje u Shakespeareovu Snu ivanjske noći čarobnim sokom zaslijepljeni mladići upućuju nekoć voljenim, a sad nevoljenim djevojkama. I u Shakespearea će se sve sretno razriješiti, djevojke će ujutro izaći iz šume, svaka ponovno sa svojim voljenim mladićem i voljena, ali izgovorene se riječi ni tamo neće moći povući ni zaboraviti (usp. Kott 1967: 171-190).

Premda nije u izravnoj vezi sa smiješnim i/ili komičnim u bračnom životu Držićevih likova, jedna se činjenica, koja mnogo kazuje o prevladavajućim tonovima u ovoj komediji, ne smije zanemariti. Riječ je, dakako, o činjenici da je Držić dvojicu muškaraca opsjednutih lijepom mladom Mandom te dvije mlade žene, nju i njezinu služavku Katu, doveo na prag incesta. Da su, milom ili silom, Turčin i Lone ostvarili svoju seksualnu žudnju - Turčin sa sestrom Mandom, kojoj želi provaliti u kuću, a Lone s kćerkom Katom, koju mu je Anisula podmetnula umjesto Mande - neobuzdano “dijete golo s krilimi” (D, str. 523), o kojem govori Krisa, u gledalištu ne bi proizvelo smijeh nego grozu.

Napokon, još samo jedna napomena o bračnoj "pokori” u komediji Tripče de Utolče. Ako Držićeva publika na praizvedbi komedije Tripče de Utolče u Džovinoj ogorčenoj kletvi "Da je proklet oni čas i oni hip u koji za te dođoh" (D, str. 523) nije prepoznala "crnu" inačicu Menčetićeve petrarkističke hvale "Blaženi čas i hip najprvo kad sam ja / vidil tvoj obraz lip od koga slava sja" te iskaz ženina dubokog razočarenja brakom i boli zbog nestanka ljubavi i kršenja svih obećanja danih u prvim dvjema Green- 
blattovim etapama razvoja muško-ženskih odnosa, "prosidbi" $i$ "vjenčanju”, onda je teško i pretpostaviti što je uopće i je li išta prepoznala, shvatila, prihvatila od Držićeve komedije "nevoljnih brakova" u kojoj, kako slijedi i iz tumačenja Dunje Fališevac, uz komiku i smijeh ima gorčine, pa i tjeskobe.

\section{LITERATURA}

Držić, Marin. 1987. Djela, priredio, uvod i komentare napisao Frano Čale. Zagreb : Centar za kulturnu djelatnost.

Blečić, Martina. 2015. John L. Austin, Kako djelovati riječima, prevela Andrea Milanko, priredio Ivan Marković (Zagreb: Disput, 2014), "Prolegomena", sv. 14, br. 2, str. 225-230.

Čale, Frano. 1987. O životu i djelu Marina Držića, u: Marin Držić, Djela, priredio, uvod i komentare napisao Frano Čale. Zagreb: Centar za kulturnu djelatnost, str. 9-168.

Čale Feldman, Lada. 2012. Još o Držićevoj dužno priznatoj “krađi”: Amphitruo u Arkulinu, u: U san nije vjerovati, Zagreb: Disput.

Fališevac, Dunja. 2007. Stari Freud u posjetu Marinu Držiću (Smiješno i komično u Držića), u: Dubrovnik otvoreni i zatvoreni grad. Studije o drubrovačkoj književnoj kulturi. Zagreb : Naklada Ljevak, str. 107-132.

Fališevac, Dunja. 2013. Rezignirani renesansni “junak” Tripče, u: Slike starog Dubrovnika: Filološke i književnoantropološke studije. Zagreb: Matica hrvatska, str. $117-133$.

Greenblatt, Stephen. 2010. Will u vremenu. Kako je Shakespeare postao Shakespeare, prev. Dinko Telećan. Zagreb: Fraktura.

Janeković Römer, Zdenka. 1994. Rod i grad. Dubrovačka obitelj od XIII do XV stoljeća. Dubrovnik: Zavod za povijesne znanosti Hrvatske akademije znanosti i umjetnosti u Dubrovniku.

Janeković Römer, Zdenka. 2008. Obitelj, u: Leksikon Marina Držića, ur. Slobodan P. Novak et al. Zagreb: Leksikografski zavod Miroslav Krleža, str. 552-553.

Kott, Jan. ${ }^{2} 1967$. Titania and the Ass's Head, u: Shakespeare our Contemporary, prev. Boleslaw Taborski. London: Mathuen.

Levenson, Jill. 1990. Comedy, u: The Cambridge Companion to English Renaissance Drama, ur. A. R. Braunmuller \& Michael Hattaway. Cambridge: Cambridge University Press.

Menandar. 1981. Mrzovoljnik, prev. Marina Bricko, "Latina et graeca", sv. 9, br. 18.

Novak, Slobodan P. 1984. Planeta Držić. Držić i rukopis vlasti. Zagreb: Centar za kulturnu djelatnost.

Pavis, Patrice. 2004. Pojmovnik teatra, prev. Jelena Rajak. Zagreb: Akademija dramske umjetnosti - Centar za dramsku umjetnost - Izdanja Antibarbarus.

Pfister, Manfred. 1998. Drama. Teorija i analiza, prev. Marijan Bobinac. Zagreb: Hrvatski centar ITI. 
Segal, Erich. ${ }^{2}$ 1987. Roman Laughter: The Comedy of Plautus. Oxford: Oxford University Press.

Turner, Victor. 1989. Od rituala do teatra. Ozbiljnost ljudske igre, prev. Gordana Slabinac. Zagreb: August Cesarec.

Weitz, Eric. 2009. The Cambridge Introduction to Comedy. Cambridge: Cambridge University Press.

\section{SUMMARY}

\section{AMUSING AND/OR COMICAL IN THE MARITAL LIFE OF DRŽIĆ'S CHARACTERS}

The paper draws on two papers written by Dunja Fališevac - on aged Freud's visit to Marin Držić, and on the resigned renaissance "hero" Tripče - but also on the hypothesis that renaissance comedies "simultaneously educe two different, well arranged sequences: narration and rhetorical argument" (Jill Levenson) as well as the three stages of male-female relationship which Steven Greenblatt names "proposal, marriage and penance". The paper analyzes courtship and proposal patterns in Grižula and Skup (peripherally also in Dundo Maroje), a staged wedding in Arkulin and "unwilling marriages" as "penance" in the comedy Tripče de Utolče. The analysis focuses on their amusing and comic features.

Keywords: Marin Držić, renaissance comedy, patterns of courtship, amusing and comic 